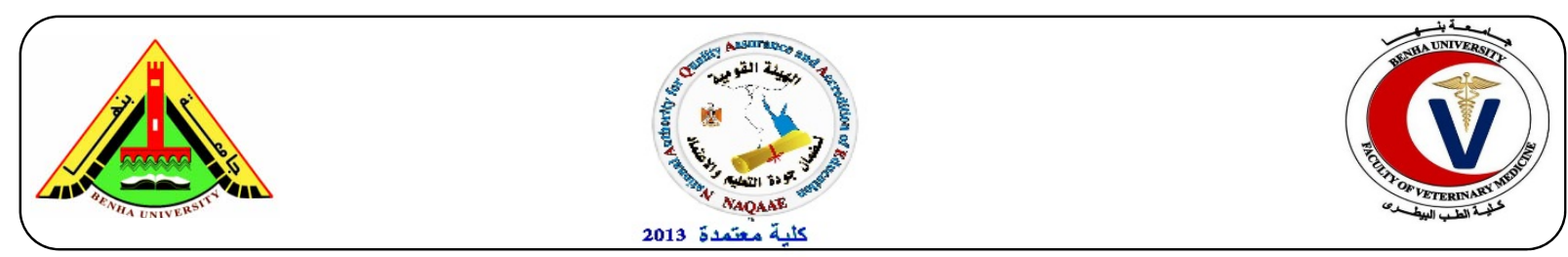

\title{
Studies on the hygienic status of animal carcasses and their contact surfaces in some butchery shops
}

\author{
Wageh Sobhy Darwish $^{1^{*}}$, Amira Samir Atia ${ }^{2}$ and Ahmed Elsayed Tharwat ${ }^{1}$ \\ ${ }^{1}$ Food Control Department, Faculty of Veterinary Medicine, Zagazig University, Zagazig, Egypt \\ ${ }^{2}$ Department of Veterinary Hygiene, Faculty of Veterinary Medicine, Zagazig University, Zagazig, Egypt \\ *Correspondence to Dr. Wageh Sobhy Darwish: wagehdarwish@yahoo.ca; wagehdarwish@zu.edu.eg
}

\begin{abstract}
A B S T R A C T
Cross-contamination of animal carcasses and their contact surfaces at any stage of meat handling is one major aspect in production of meat of high keeping quality. Thus, the objective of this study was to investigate the hygienic status of the animal carcasses (cattle, buffaloes, camel and sheep) and their contact surfaces (cutting boards, walls, knives, and butcher hands) in butchery shops among urban and rural areas in Sharkia province, Egypt. Microbial indicators for the hygienic measures adopted at butchery shops including total bacterial counts (TBC), total Enterobacteriacae counts (TEC), most probable number (MPN) of coliforms, total Staphylococcus aureus counts (TSC), total mould counts (TMC) and total yeast counts (TYC) were investigated. The results achieved in this study declared that cross-contamination of animal carcasses and their contact surfaces is well-observed and should be considered as an important factor that should be included in the microbiological risk assessments. Therefore, we recommend adoption of strict hygienic measures in all handling steps of animal carcasses.
\end{abstract}

Key words: Butchery shops, animal carcasses, hygienic measures

(http://www.bvmj.bu.edu.eg)

(BVMJ-31(2): 289-296, 2017)

\section{INTRODUCTION}

Microbial contamination of the surfaces of the animal carcasses is mainly due to the existence of a wide range of microorganisms in the environment of the meat processing plants, slaughterhouses and butcher-shops. This cross-contamination takes place at different stages of processing starting from animal slaughtering, skinning, evisceration, deboning, carcass transportation and distribution, subsequently, leading to contamination of the raw meat with a vast array of microorganisms including food-poisoning organisms which might lead to severe public health implications (Borch and Arinder, 2002; McEvoy et al., 2003). The sources of microbial contamination of animal carcasses include but not limited to the animal itself and carcass-contact surfaces such as butcher hands, knives, cutting boards, walls, floors, air and water (Darwish et al., 2016b; Mizakova et al., 2002). There are many microbial indicators for the hygienic measures of the meat-processing and handling plants which include total bacterial counts (TBC), total Enterobacteriacae counts (TE C), most probable number (MPN) of coliforms, total Staphylococcus aureus counts (TSC), total mould counts (TMC) and total yeast counts (TYC). These indicators give a clear image about the hygienic practices and measures adopted during carcass handling and processing and finally affect on the production of meat of high keeping quality (Mossel et al., 1995). One major task of the meat and environmental hygiene is to ensure application of the hygienic measures at meat processing plants and retail shops including butchery shops. Thus, studies that focus on monitoring the hygienic status of animal slaughterhouses, butchery shops and retail markets should be continuously performed.

Therefore, this study was undertaken to investigate the hygienic status of the animal carcasses (cattle, buffaloes, camel and sheep) and their contact surfaces (cutting boards, walls, knives, and butcher hands) in butchery shops among urban and rural areas in Sharkia province, Egypt during the period between June to December 2016.

\section{MATERIAL AND METHODS}

2.1. Collection of Samples: 
Hundred and sixty swab samples were collected randomly and equally from animal carcasses and their contact surfaces fxrom butchery shops at both urban and rural areas in Sharkia province, Egypt. These samples were divided as following: $10 \mathrm{swab}$ samples (each swab sample represents a space area of $1 \times 1 \mathrm{~cm}$ ) from each of cattle, buffaloes, camel and sheep carcasses from the surface of the shoulder region from both of urban and rural areas. In addition, 10 swab samples were further collected and representing a space area of one $\mathrm{cm}^{2}$ for each of cutting-boards, walls, knives and butcher hands at butchery shops from both of urban and rural areas in Sharkia province, Egypt. Samples were collected in the period between June to December 2016.

\subsection{Microbiological examinations:}

Swabbing of a space area of $1 \mathrm{~cm}^{2}$ from each of the examined samples was done using sterile gauze swab moistened in a sterile $0.9 \%$ saline solution, then moved to a sterile test tube containing $10 \mathrm{ml}$ of a sterile $0.9 \%$ saline solution. Swabbing by another dry swab was done, then moved to the representative sample test tube. Shacked well and this dilution is considered as $10^{-1}$, then decimal dilutions were done (American Public Health Association (APHA), 2001). Take $1 \mathrm{ml}$ from the desired dilution for each Petri dish or test tube for the following examinations:

\subsubsection{Total Bacterial Counts (TBC):}

Total bacterial count was estimated using the method of APHA (2001). In brief, pipet one ml from each swab representative tube to clean and sterile Petri dish. Add 12-15 ml of Plate count agar (Difco Laboratories, Detroit, Michigan, USA) cooled to $45 \pm 1^{\circ} \mathrm{C}$ for each Petri dish, mix well, then leave to solidify and incubate at inverted position for $48 \mathrm{~h}$ at $35 \pm 2{ }^{\circ} \mathrm{C}$. Record all colonies including pinpoint size colony forming units as TBC in plates with 25-250 colonies per dish.

$\mathrm{TBC} / \mathrm{cm}^{2}=$ average No. of colonies $\times$ reciprocal of dilution

Counted colonies expressed as $\log 10 \mathrm{cfu} / \mathrm{cm}^{2}$.

\subsubsection{Determination of total Enterobacteriacae count (TEC):}

Total Enterobacteriacae count was estimated using the method of APHA (2001). In short, from the original and the subsequent prepared dilutions one ml was poured onto an empty pre-sterilized Petri dish in duplicate plates, then $12-15 \mathrm{ml}$ of violet red bile glucose agar (Difco Laboratories, Detroit, Michigan, USA) cooled to $45 \pm 1{ }^{\circ} \mathrm{C}$ for each Petri dish was poured. The plates were incubated at $37^{\circ} \mathrm{C}$ for $24 \mathrm{~h}$. All large pink to red colonies were counted.

Counted colonies expressed as $\log 10 \mathrm{cfu} / \mathrm{cm}^{2}$.

\subsubsection{Determination of most probable number of Coliforms (MPN):}

Three tubes most probable number (MPN) method recommended (APHA, 2001) was adopted. In brief, one $\mathrm{ml}$ of each dilution was used to inoculate separately into three test tubes containing MacConkey broth with inverted Durham's tubes. The inoculated tubes were incubated at $37^{\circ} \mathrm{C}$ for $24-$ $48 \mathrm{hrs}$. Positive tubes showing acid (yellow color) and gas production in inverted Durham's tubes were recorded. The most probable number of coliforms was calculated according to the recommended tables.

\subsubsection{Total Staphylococcus aureus count (TSC):}

Then microbiological processing of the samples for the isolation of Staph. aureus was performed using Baird Parker agar (Difco Laboratories, Detroit, Michigan, USA) through the standard procedure (APHA, 2001). Suspected colonies (black, shiny convex colonies, $1-1.5 \mathrm{~mm}$ in diameter and surrounded by clear halo zone) were subcultured on blood agar plates (Difco Laboratories, Detroit, Michigan, USA) and incubated for 24 hours at $37^{\circ} \mathrm{C}$. To identify Staph. aureus, Gram stain, catalase, mannitol fermentation, coagulase, DNAs and VogesProskauer (VP) tests were performed on suspected colonies according to Quinn et al. (2002). Total Staph. aureus count was expressed as:

Total Staph. aureus count $=$ Positive colonies $\mathrm{x}$ reciprocal dilution factor

Counted colonies expressed as $\log 10 \mathrm{cfu} / \mathrm{cm}^{2}$.

\subsubsection{Determination of the total mould and yeast counts:}

The total mould and yeast counts were determined by culturing duplicate plates on Sabouraud's dextrose agar media (Oxoid, Basingstoke, UK) supplemented with chloramphenicol $100 \mathrm{mg} / \mathrm{L}$ followed by incubation in dark at $25^{\circ} \mathrm{C}$ for $5-7$ days. During the incubation time, the plates were examined daily for the fungal growth. Estimation of total mould and yeast was obtained by direct counting of the cultured agar plates (APHA, 2001).

Counted colonies expressed as $\log 10 \mathrm{cfu} / \mathrm{cm}^{2}$.

\subsection{Statistical analysis:}

All values are expressed as means $\pm \mathrm{SD}$, and all measurements were carried out in duplicates. Bacterial counts were converted into base 10 
logarithms of colony forming units per $\mathrm{cm}^{2}(\log 10$ $\left.\mathrm{cfu} / \mathrm{cm}^{2}\right)$. Statistical significance was evaluated using the Tukey-Kramer HSD test (JMP statistical package; SAS Institute Inc., Cary, NC). In all analyses, $P<0.05$ was taken to indicate statistical significance Gomez and Gomez (1984).

\section{RESULTS}

The achieved results in this study declared that $100 \%$ of examined animal carcasses and their contact surfaces were contaminated with mesophilic bacteria (Table 1). Members of Enterobacteriacae family contaminated cattle and buffaloes carcasses with $50 \%$ for samples collected from urban areas for both species and with $80 \%$ and $70 \%$ cattle and buffaloes slaughtered at rural areas respectively. Members of this family contaminated $50 \%$ of camel and sheep carcasses slaughtered in urban and rural areas. Additionally Enterobacteriacae was detected in all animal contact surfaces with variable percentages ranged from $40 \%$ to $100 \%$ as clear in table 1 . Coliforms bacteria were determined in the examined samples in this study, positive samples were ranged from $30 \%$ to $100 \%$ of the examined samples. Staphylococcus aureus was also isolated and detected in all examined samples with variable percentages ranged from $30 \%$ to $60 \%$. Fungal contamination of animal carcasses and their contact surfaces was very clear in this study. The positive samples for both yeast and mould contamination ranged from $30 \%$ to $100 \%$ (Table $1)$.

Table 1: Microbiological contamination percentages (\%) of the examined animal carcasses and their contact surfaces among urban and rural areas in Sharkia province, Egypt

\begin{tabular}{|c|c|c|c|c|c|c|c|c|}
\hline & & $\mathrm{N}$ & $\mathrm{TBC}$ & TEC & MPN & $\mathrm{TSC}$ & TMC & TYC \\
\hline \multirow[t]{2}{*}{ Cattle } & Urban & 10 & $100 \%$ & $50 \%$ & $50 \%$ & $50 \%$ & $60 \%$ & $40 \%$ \\
\hline & Rural & 10 & $100 \%$ & $80 \%$ & $70 \%$ & $50 \%$ & $80 \%$ & $60 \%$ \\
\hline \multirow[t]{2}{*}{ Buffaloes } & Urban & 10 & $100 \%$ & $50 \%$ & $50 \%$ & $60 \%$ & $50 \%$ & $30 \%$ \\
\hline & Rural & 10 & $100 \%$ & $70 \%$ & $60 \%$ & $50 \%$ & $80 \%$ & $50 \%$ \\
\hline \multirow[t]{2}{*}{ Camel } & Urban & 10 & $100 \%$ & $50 \%$ & $40 \%$ & $40 \%$ & $50 \%$ & $30 \%$ \\
\hline & Rural & 10 & $100 \%$ & $50 \%$ & $50 \%$ & $50 \%$ & $60 \%$ & $50 \%$ \\
\hline \multirow[t]{2}{*}{ Sheep } & Urban & 10 & $100 \%$ & $50 \%$ & $50 \%$ & $40 \%$ & $50 \%$ & $30 \%$ \\
\hline & Rural & 10 & $100 \%$ & $50 \%$ & $50 \%$ & $40 \%$ & $50 \%$ & $40 \%$ \\
\hline \multirow[t]{2}{*}{ Cutting boards } & Urban & 10 & $100 \%$ & $60 \%$ & $60 \%$ & $60 \%$ & $100 \%$ & $40 \%$ \\
\hline & Rural & 10 & $100 \%$ & $80 \%$ & $100 \%$ & $60 \%$ & $100 \%$ & $70 \%$ \\
\hline \multirow[t]{2}{*}{ Walls } & Urban & 10 & $100 \%$ & $80 \%$ & $80 \%$ & $50 \%$ & $100 \%$ & $60 \%$ \\
\hline & Rural & 10 & $100 \%$ & $100 \%$ & $100 \%$ & $60 \%$ & $100 \%$ & $80 \%$ \\
\hline \multirow[t]{2}{*}{ Knives } & Urban & 10 & $100 \%$ & $40 \%$ & $30 \%$ & $40 \%$ & $50 \%$ & $30 \%$ \\
\hline & Rural & 10 & $100 \%$ & $40 \%$ & $40 \%$ & $40 \%$ & $50 \%$ & $30 \%$ \\
\hline \multirow[t]{2}{*}{ Butcher hands } & Urban & 10 & $100 \%$ & $40 \%$ & $30 \%$ & $30 \%$ & $40 \%$ & $30 \%$ \\
\hline & Rural & 10 & $100 \%$ & $40 \%$ & $30 \%$ & $40 \%$ & $40 \%$ & $30 \%$ \\
\hline
\end{tabular}

$\mathrm{N}=$ Number of Samples; TBC $=$ Total Bacterial Counts; TEC $=$ Total Enterobacteriacae Counts. MPN $=$ Most probable Number of Coliforms; TSC $=$ Total Staphylococcus aureus count; TMC $=$ Total Mould Counts; TYC $=$ Total Yeast Counts

Total bacterial count (TBC) $\left(\log 10 \mathrm{cfu} / \mathrm{cm}^{2}\right)$ was estimated in the collected samples, the achieved results declared that the mean values of TBC were $7.05 \pm 0.14$ and $7.98 \pm 0.25 \log 10 \mathrm{cfu} / \mathrm{cm}^{2}$ in cattle samples collected from urban and rural areas respectively (Figure 1A). These values were $6.95 \pm 0.23$ and $7.75 \pm 0.24 \log 10 \mathrm{cfu} / \mathrm{cm}^{2}$ in the buffaloes samples respectively, camel samples were significantly lower than cattle and buffaloes samples. Sheep samples had the lowest TBC compared with other animal species in both urban $(5.17 \pm 0.20)$ and rural (5.5 \pm 0.32$)$ areas respectively as clear in figure $1 \mathrm{~A}$. In the second part of this study, we estimated TBC from the carcasses' contact surfaces, the mean values of TBC in cutting boards were $7.19 \pm 0.55$ and $8.20 \pm 0.19 \log 10$ $\mathrm{cfu} / \mathrm{cm}^{2}$ from samples collected from both urban and rural areas respectively (Figure 1B). Swab samples of walls had mean values of TBC of $6.95 \pm 0.42$ and $8.50 \pm 0.16 \log 10 \mathrm{cfu} / \mathrm{cm}^{2}$ from samples collected from butcher shops in both urban and rural areas respectively. Swabs obtained from knives and butcher hands especially from urban areas had the lowest TBC compared with other contact surfaces (Figure 1B). Total Enterobacteriacae count (TEC) $\left(\log 10 \mathrm{cfu} / \mathrm{cm}^{2}\right)$ was estimated in the collected samples as clear in figure 2A and B. Samples collected from cattle and buffaloes carcasses in both urban and rural areas had significantly $(p<0.05)$ the highest TEC 
compared with samples collected from camel and sheep carcasses (Figure 2A). Samples collected from cutting boards had mean values of TEC of $5.5 \pm 0.33$ and $6.2 \pm 0.18 \log 10 \mathrm{cfu} / \mathrm{cm}^{2}$ in samples collected from both urban and rural areas respectively. These values were $5.80 .5 \pm 0.22$ and $6.50 \pm 0.15 \log 10 \mathrm{cfu} / \mathrm{cm}^{2}$ in swab samples of walls collected from both urban and rural areas respectively (Figure 2B). Mean values of TEC in swab samples collected from knives from both urban and rural areas were $3.20 \pm 0.13$ and $3.10 \pm 0.18 \log 10 \mathrm{cfu} / \mathrm{cm}^{2}$ respectively. These values were $3.50 \pm 0.14$ and $3.70 \pm 0.20 \log 10$ $\mathrm{cfu} / \mathrm{cm}^{2}$ in swab samples of butcher hands collected from both urban and rural areas respectively (Figure 2B).

The recorded results in figure $3 \mathrm{~A}$ and $\mathrm{B}$ demonstrate most probable number (MPN) of coliforms in animal carcasses and their contact surfaces. It is clear from the achieved results that cattle samples collected from both urban and rural areas had the highest MPN of coliforms compared with other animal species with mean values of $3.50 \pm 0.13$ and $4.57 \pm 0.18 \quad \log 10 \mathrm{MPN} / \mathrm{cm}^{2}$ respectively. These values were $3.20 \pm 0.14$ and $3.55 \pm 0.21 \log 10 \mathrm{MPN} / \mathrm{cm}^{2}$ in swab samples collected from buffaloes' surfaces in both urban and rural areas respectively. Sheep samples had significantly $(p<0.05)$ the lowest MPN of coliforms (Figure 3A). Regarding the animal carcasses' contact surfaces, it is clear from the achieved results that swab samples of both walls and cutting boards had significantly $(p<0.05)$ higher MPN of coliforms particularly, in samples collected from the rural areas (Figure 3B).

Total Staph. aureus count $\left(\log 10 \mathrm{cfu} / \mathrm{cm}^{2}\right)$ was estimated in the examined samples. Mean values of total Staph. aureus count in cattle samples collected from both urban and rural areas were $3.70 \pm 0.17$ and $4.50 \pm 0.15 \quad \log 10 \quad \mathrm{cfu} / \mathrm{cm}^{2}$ respectively. These values were $3.50 \pm 0.22$ and $4.75 \pm 0.18 \log 10 \mathrm{cfu} / \mathrm{cm}^{2}$ in buffaloes' samples collected from both urban and rural areas respectively. In camel samples collected from both urban and rural areas, the mean values of total Staph. aureus count were $3.30 \pm 0.25$ and $3.82 \pm 0.22$ $\log 10 \mathrm{cfu} / \mathrm{cm}^{2}$ respectively, while in sheep samples, these values were the lowest $2.40 \pm 0.16$ and $3.31 \pm 0.20 \log 10 \mathrm{cfu} / \mathrm{cm}^{2}$ from both urban and rural areas respectively (Figure 4A). Total Staph. aureus count $\left(\log 10 \mathrm{cfu} / \mathrm{cm}^{2}\right)$ was also estimated in the swab samples collected from animal carcasses' contact surfaces as clear in figure 4B. Butcher hands had the highest total Staph. aureus count $\left(\log 10 \mathrm{cfu} / \mathrm{cm}^{2}\right)$ with mean values of $5.50 \pm 0.18$ and $5.77 \pm 0.22 \log 10 \mathrm{cfu} / \mathrm{cm}^{2}$ from both urban and rural areas respectively (Figure 4B).
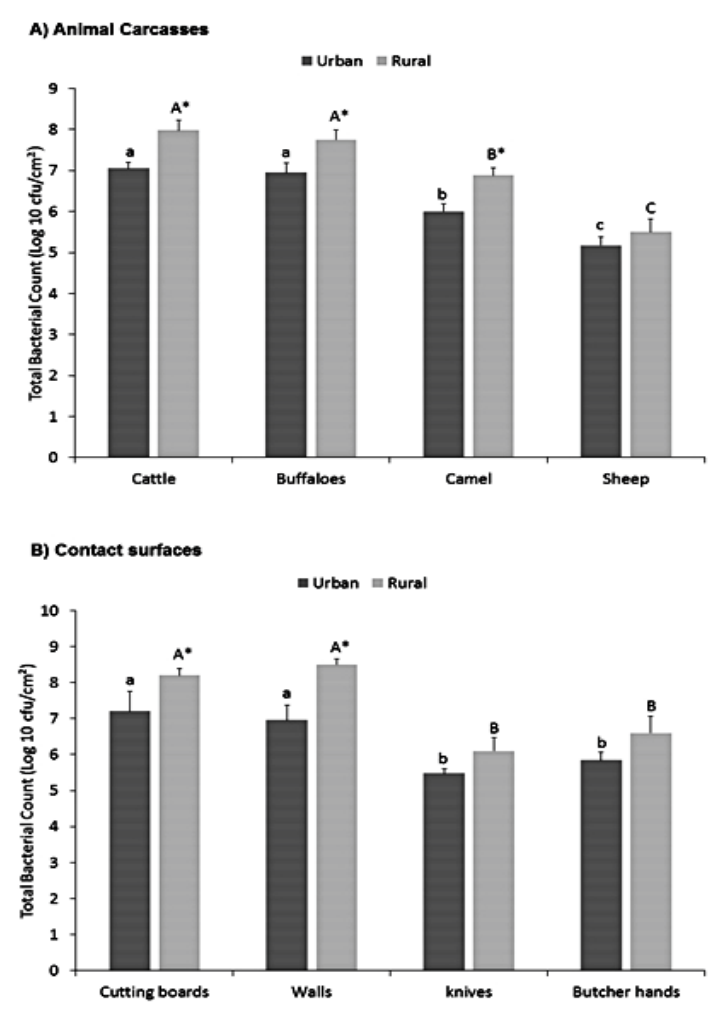

Figure 1. Total bacterial count among different animal carcasses and their contact surfaces Total bacterial count of A) Animal carcasses B) Contact surfaces. Values represent means $\pm \operatorname{SD}\left(\log \mathrm{cfu} / \mathrm{cm}^{2}\right)$ of ten samples from each animal carcass or their contact surface. Columns carrying different small letters differ significantly among urban locations at $P<0.05$. Columns carrying different large letters differ significantly among rural locations at $P<0.05$. Columns carrying star mark differ significantly among both urban and rural locations at $P<0.05$.

Total mould count (TMC) $\left(\log 10 \mathrm{cfu} / \mathrm{cm}^{2}\right)$ was also tested in the examined samples. It is clear from the obtained results that buffaloes' samples had the highest TMC followed by cattle, camel and sheep samples. TMC was also significantly $(p<0.05)$ higher in samples collected from rural areas compared with urban areas. The mean values of TMC in buffaloes' samples were $4.30 \pm 0.18$ and $5.50 \pm 0.22 \log 10 \mathrm{cfu} / \mathrm{cm}^{2}$ from both urban and rural areas respectively (Figure 5A). Regarding TMC in the carcasses' contact surfaces, swab samples collected from the walls and cutting boards had significantly the highest TMC compared with swab samples of knives and butcher hands in particular in rural samples (Figure 5B).

Total yeast count (TYC) $\left(\log 10 \mathrm{cfu} / \mathrm{cm}^{2}\right)$ was estimated in the collected samples, the achieved results in figure 6 declared that the mean values of 

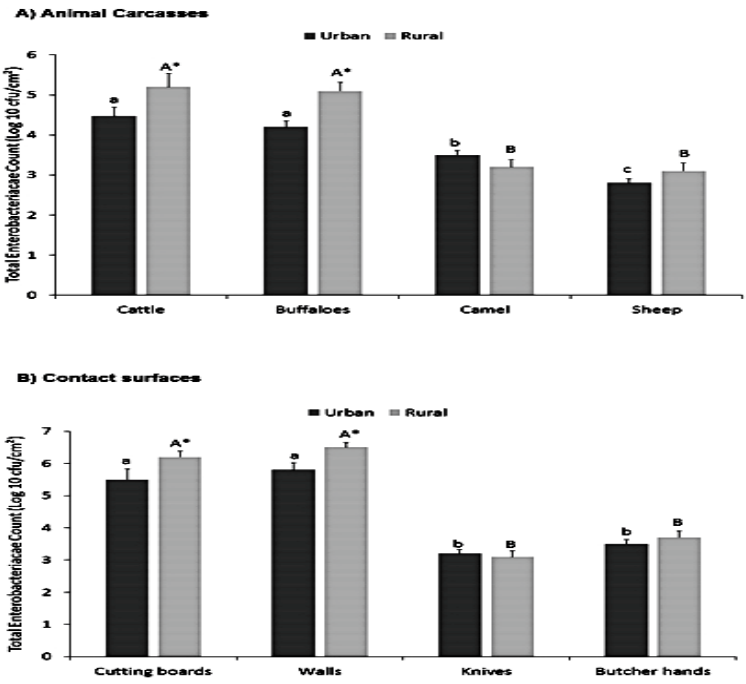

Figure 2. Total enterobacteriacae count among different animal carcasses and their contact surfaces

Total enterobacteriacae count of A) Animal carcasses B) Contact surfaces. Values represent means \pm SD (Log $\mathrm{cfu} / \mathrm{cm}^{2}$ ) of ten samples from each animal carcass or their contact surface. Columns carrying different small letters differ significantly among urban locations at $P<$ 0.05 . Columns carrying different large letters differ significantly among rural locations at $P<0.05$. Columns carrying star mark differ significantly among both urban and rural locations at $P<0.05$.
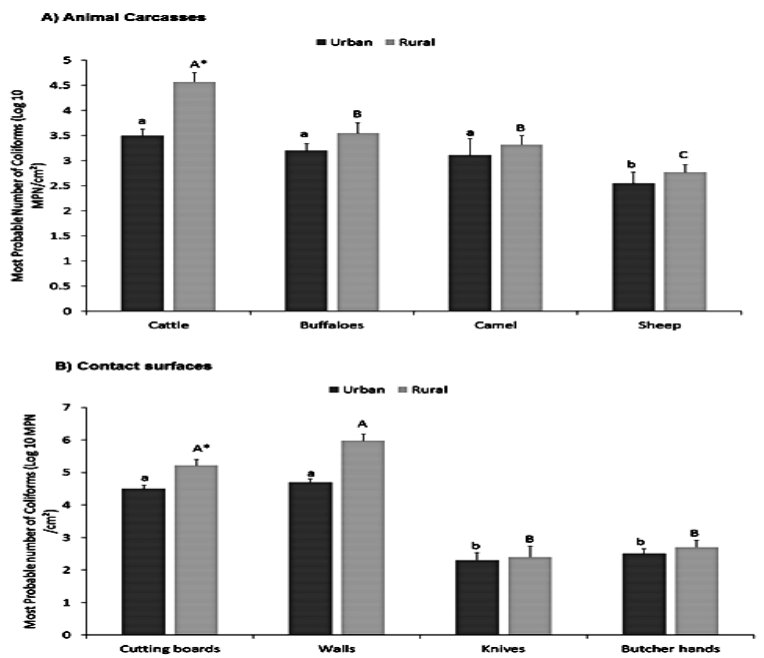

Figure 3. Most probable number of coliforms among different animal carcasses and their contact surfaces

Most probable number of coliforms of A) Animal carcasses B) Contact surfaces. Values represent means $\pm \mathrm{SD}\left(\log \mathrm{cfu} / \mathrm{cm}^{2}\right)$ of ten samples from each animal carcass or their contact surface. Columns carrying different small letters differ significantly among urban locations at $P<0.05$. Columns carrying different large letters differ significantly among rural locations at $P<$ 0.05 . Columns carrying star mark differ significantly among both urban and rural locations at $P<0.05$.
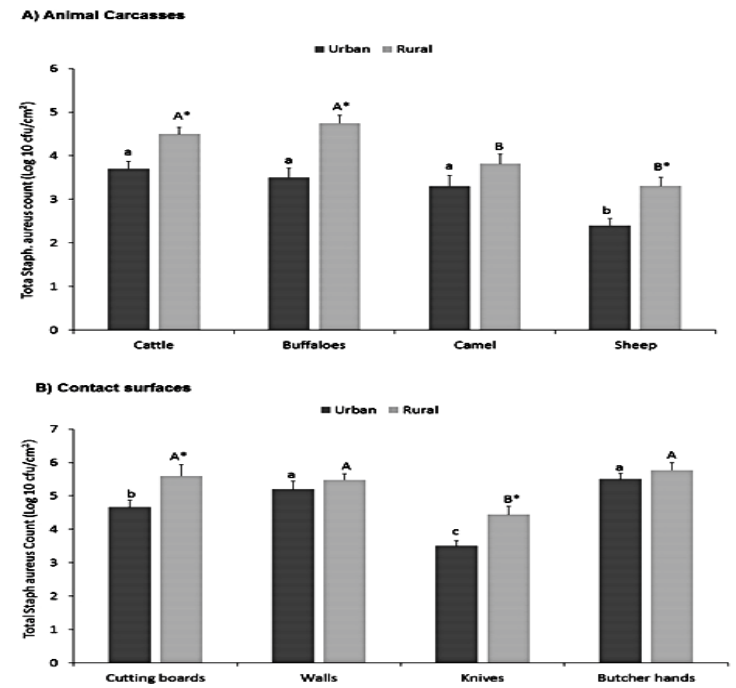

Figure 4. Total Staphylococcus aureus count among different animal carcasses and their contact surfaces

Total Staphylococcus aureus count of A) Animal carcasses B) Contact surfaces. Values represent means $\pm \mathrm{SD}\left(\mathrm{Log} \mathrm{cfu} / \mathrm{cm}^{2}\right)$ of ten samples from each animal carcass or their contact surface. Columns carrying different small letters differ significantly among urban locations at $P<0.05$. Columns carrying different large letters differ significantly among rural locations at $P<$ 0.05 . Columns carrying star mark differ significantly among both urban and rural locations at $P<0.05$.
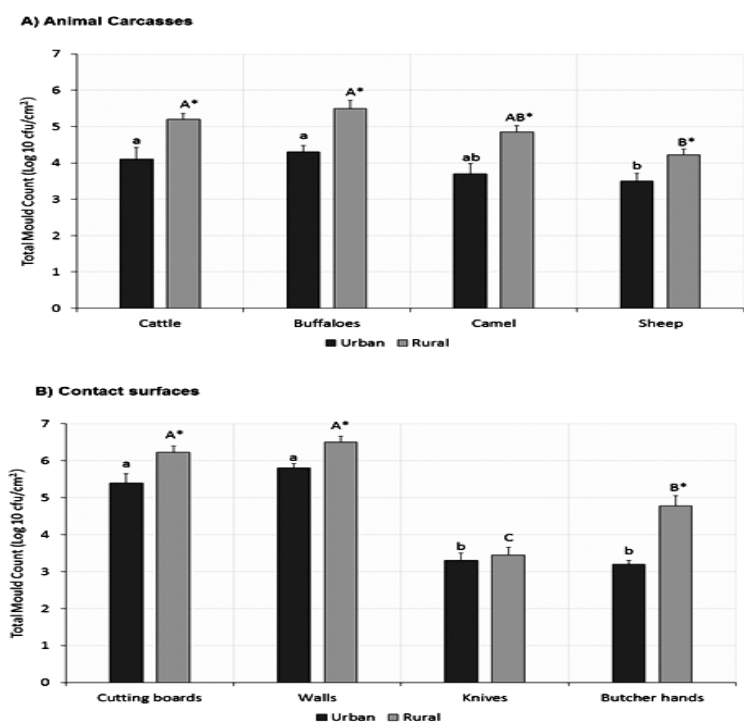

Figure 5. Total mould count among different animal carcasses and their contact surfaces Total mould count of A) Animal carcasses B) Contact surfaces. Values represent means $\pm \operatorname{SD}\left(\log \mathrm{cfu} / \mathrm{cm}^{2}\right)$ of ten samples from each animal carcass or their contact surface. Columns carrying different small letters differ significantly among urban locations at $P<0.05$. Columns carrying different large letters differ significantly among rural locations at $P<0.05$. Columns carrying star mark differ significantly among both urban and rural locations at $P<0.05$. 
TYC were $3.90 \pm 0.24$ and $4.80 \pm 0.22 \log 10 \mathrm{cfu} / \mathrm{cm}^{2}$ in in cattle samples collected from urban and rural areas respectively (Figure 6A). These values were $3.66 \pm 0.16$ and $4.32 \pm 0.21 \log 10 \mathrm{cfu} / \mathrm{cm}^{2}$ in the buffaloes' samples collected from urban and rural areas respectively. Camel samples were significantly lower than cattle and buffaloes samples. Sheep samples had the lowest TYC compared with other animal species in both urban $(2.80 \pm 0.14)$ and rural $(3.66 \pm 0.18)$ areas respectively as clear in figure 6A. We further estimated TYC from the carcasses' contact surfaces, the mean values of TYC in cutting boards were $4.80 \pm 0.28$ and $5.50 \pm 0.16 \log 10 \mathrm{cfu} / \mathrm{cm}^{2}$ from samples collected from both urban and rural areas respectively (Figure 6B). Swab samples of walls had mean values of TYC of $5.50 \pm 0.18$ and $6.80 \pm 0.20 \log 10 \mathrm{cfu} / \mathrm{cm}^{2}$ from samples collected from butcher shops in both urban and rural areas respectively. Swabs obtained from knives and butcher hands especially from urban areas had the lowest TYC compared with other contact surfaces (Figure 6B).
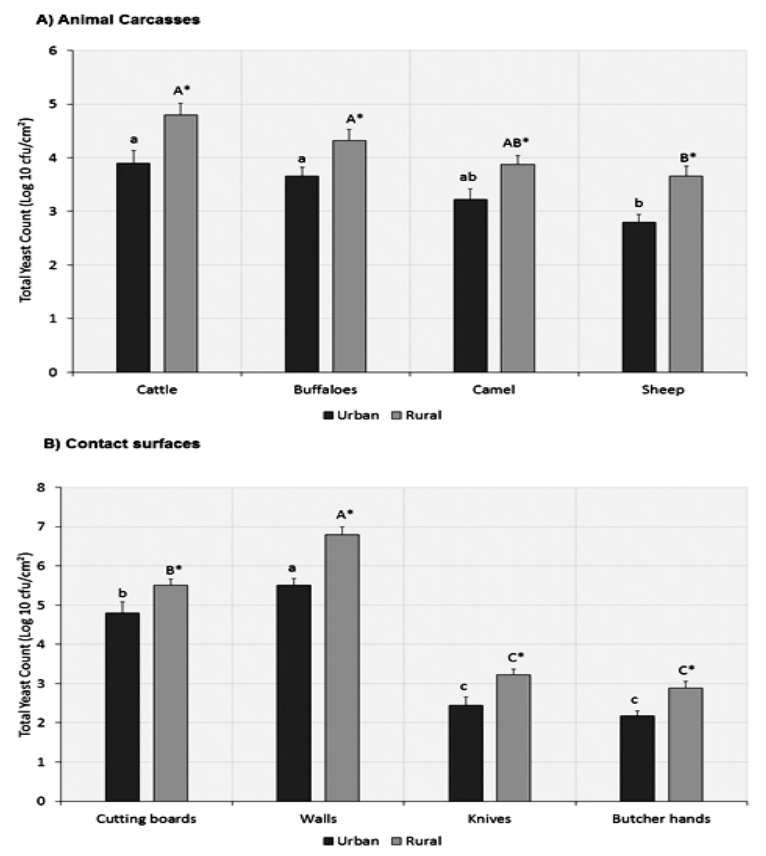

Figure 6. Total yeast count among different animal carcasses and their contact surfaces Total yeast count of A) Animal carcasses B) Contact surfaces. Values represent means $\pm S D\left(\log \mathrm{cfu} / \mathrm{cm}^{2}\right)$ of ten samples from each animal carcass or their contact surface. Columns carrying different small letters differ significantly among urban locations at $P<0.05$. Columns carrying different large letters differ significantly among rural locations at $P<0.05$. Columns carrying star mark differ significantly among both urban and rural locations at $P<0.05$.

\section{DISCUSSION}

In spite of the increasing attention of the public authorities and consequently of the food operators towards food hygiene and food safety, the consumption of foods contaminated with pathogenic microorganisms or their toxins remains one of the major causes of disease, hospitalization, and economic loss (Centers for Disease Control and Prevention (CDC), 2013), and millions of people suffer from preventable foodborne diseases every year, which are considered as the growing public health problem and imply a great impact worldwide (Maheux et al., 2009).

Since one major task of meat hygiene is to protect both the food product and the meat handlers from cross-contamination, thus, this study was carried out to investigate an important food safety issue related to the control of hygienic measures in the butchery shops.

It is clear from the achieved results that TBC was significantly higher in cattle and buffaloes' carcasses compared with camel and sheep ones in both urban and rural locations. This may be attributed to the poor hygienic practices adopted during handling of the carcasses in the rural butchery shops. The high number of TBC indicated the poor hygienic conditions during meat handling (Durmaz et al., 2015). In parallel, high TBC was observed in the carcass contact surfaces, in particular cutting boards and walls. These findings go in agreement with Weinstein (1991) who reported that Poor personal hygiene caused more than $90 \%$ of the sanitary problems in the food service industry. In addition, government statistics showed that improper hand washing alone accounts for more than $25 \%$ of all food borne disease. Poor hygiene at butchery shops resulted in higher contamination, which may be due to dirty walls, cutting boards, unhygienic handling, and lack of knowledge of hygienic practices was also reported (Tambekar et al., 2008). Furthermore, Stoica et al. (2014), reported that the occurrence of the microbiological hazards in the animal carcasses is unavoidable because the microorganisms are present on animal, environment and through the carcass contact surfaces which are liable to harbor various microorganisms.

The total enterobacteriacae count in meat has been recommended as an indicator of the contamination of meat by intestinal flora. Therefore, their presence in high number indicated inadequacy of general hygiene in meat-processing plant (International Commission of Microbiological Specification for Foods (ICMSF), 1996). It is clear from the achieved results that swab samples of cattle and buffaloes slaughtered at rural areas had the highest total enterobacteriacae count. Similarly, higher counts were reported in the 
swab samples collected from walls and cutting boards of the butchery shops at the same locations. This indicates improper hygienic measures adopted during handling of the carcasses and crosscontamination with the carcass-contact surfaces. The results achieved in this study go in agreement with the results achieved by Algabry et al. (2012), they reported high total enterobacteriacae count cattle carcasses collected from butcher shops at Alexandria province, Egypt. Many species of enterobacteriacae have been reported to cause health hazard while other species cause spoilage and deterioration of meat (ICMSF, 1996).

Coliform bacteria are significant microbiological sanitary indicators, which emphasizes hygiene in all steps of preparation and handling of meat and meat products (Darwish et al., 2015). The obtained results revealed the occurrence of the coliform bacteria in $40 \%$ to $70 \%$ of the examined animal carcasses and $30 \%$ to $100 \%$ of the examined contact surfaces. Cattle carcasses at rural areas had significantly the highest coliforms count followed by buffaloes, camel and finally sheep carcasses. Examination of the carcass contact surfaces revealed that cutting boards and walls had significantly the highest coliforms count. This result indicates unhygienic condition of slaughtering, preparation and handling of animal carcasses. Our results were also go in agreement with that achieved by Algabry et al. (2012), they reported high total coliforms count in cattle carcasses and their contact surfaces in butcher shops at Alexandria province, Egypt. The presence of coliform group in meat has an epidemiological interest as some of members are pathogenic and may result in serious infections and food poisoning. Thus, the coliform counts may be used as a broad base indicating fecal contamination of meat due to inadequate processing and post processing recontamination of meat (ICMSF, 1996).

The problem of Staphylococcus aureus as contaminants in the food supply remains significant on a global level, as it is a prominent causative agent of food poisoning outbreaks that were reported due to poor hygienic practices (Center for Health Protection (CHP), 2011). The results achieved in this study indicated significantly higher level of Staphylococcus aureus in the cattle and buffaloes samples collected from rural areas. Correspondingly, higher contamination level was also recorded in swab samples of butcher hands, cutting boards and walls, particularly that collected from rural areas. These results go in agreement with that reported before (Lin et al., 2009).

Staphylococcus aureus food poisoning is considered the third largest cause of food related illnesses worldwide. Its food poisoning is commonly characterized by its rapid onset, vomiting, abdominal cramps, severe diarrhea with normal or sub-normal temperature (Aydin et al., 2011). Accordingly, contamination with Staphylococcus aureus can be taken as index of sanitary conditions under which the meat is prepared and handled (Potter, 2001), and as important risk index in evaluation of safety and hygienic quality of the food (Lin et al., 2009).

The incidence of fungal contamination either mould or yeast was investigated. The obtained results revealed that the incidence of fungal contamination varied from $30 \%$ to $80 \%$ in the animal carcasses and from $30 \%$ to $100 \%$ in the carcass-contact surfaces. Cattle and buffaloes, particularly slaughtered in rural butchery shops had significantly higher total mould and total yeast counts followed by camel and sheep carcasses. These results were in agreement with the fungal contamination of the carcass-contact surfaces, especially for walls and cutting boards. The obtained results in this study were in correspondence with our previous reports (Darwish, 2016a; Darwish et al., 2016b; Darwish et al., 2014a). The incidence of meat contamination with different mould genera was investigated in different localities of the world such as Australia, Japan, Italy and Spain (Hitokoto et al., 1978; Iacumin et al., 2009; King et al., 1986; MartinSanchez et al., 2011)). Fungal contamination of meat may lead to their spoilage and production of mycotoxins with potential health hazards to human due to their carcinogenic effects, liver diseases and organ damage (Darwish et al., 2014b). Fungal contamination of animal carcasses in this study indicates inadequate sanitary measures performed during handling of carcasses starting from the abattoir level. The conditions of the environment in the slaughtering halls, stores, refrigerators and butchery shops are very suitable for the development of moulds and yeasts not only inside the meat, but also more frequently on the surface of various sorts of animal carcasses (Mizakova et al., 2002).

In conclusion, it is clear from the results achieved in this study that cross-contamination of animal carcasses and their contact surfaces is wellobserved and should be considered as an important factor that should be included in the microbiological risk assessments. Therefore, we recommend frequent cleaning of equipment and washing of walls at butchery shops by running water, disinfectants, and replace wooden cutting boards by granite to be easily disinfected. Adoption of strict hygienic measures should be followed in all handling steps of animal carcasses. 


\section{REFERENCES}

Algabry, I.M.I., Ahmed, A.A., Ibrahim, H.A.A., Samaha, I., 2012. Hygiene of Butchershop in Alexandria. Alex. J. Vet. Sci. 37, 23-31.

American Public Health Association (APHA), 2001. Compendium of methods for the microbiological examination of food, $4^{\text {th }}$ ed. American Public Health Association, Washington, D.C.

Aydin, A., Sudagidan, M., Muratoglu, K., 2011. Prevalence of staphylococcal enterotoxins, toxin genes and genetic-relatedness of foodborne Staphylococcus aureus strains isolated in the Marmara Region of Turkey. International journal of food microbiology 148, 99-106.

Borch, E., Arinder, P., 2002. Bacteriological safety issues in red meat and ready-to-eat meat products, as well as control measures. Meat science 62, 381-390.

Center for Health Protection (CHP), 2011. Scientific Committee on Enteric Infectious and Foodborne Diseases. Review of Staphylococcal Food Poisoning in Hong Kong, 1-18.

Centers for Disease Control and Prevention (CDC), 2013. Surveillance for foodborne disease outbreaks - United States, 2009-2010. Morbidity and Mortality Weekly Report 62, 41-47.

Darwish, W.S., 2016a. Studies on Mould Contamination of Some Egyptian Meat Products. Zag. Vet. J. 43, 40-49.

Darwish, W.S., El-Bayomi, R.M., El-Moaty, A.M.A., Gad, T.M., 2016b. Mould contamination and aflatoxin residues in frozen chicken meat-cuts and giblets. Jap. J. Vet. Res. 64, S167-S171.

Darwish, W.S., Elabbasy, M.T., Morshdy, A., 2014a. Prevalence of different mould genera in raw edible offal of cattle, camel and sheep. Glob. J. Agric. Food Safety Sci. 1, 213-224.

Darwish, W.S., Eldin, W.F.S., Eldesoky, K.I., 2015. Prevalence, Molecular Characterization and Antibiotic Susceptibility of Escherichia Coli Isolated from Duck Meat and Giblets. Journal of Food Safety 35, 410-415.

Darwish, W.S., Ikenaka, Y., Nakayama, S.M., Ishizuka, M., 2014b. An overview on mycotoxin contamination of foods in Africa. The Journal of veterinary medical science 76, 789-797.

Durmaz, H., Aygun, O., Sancak, H., 2015. The microbiological quality of grilled meats (Kebab) and salads consumed in Sanliurfa restaurants. Int. J. Sci. Technol. Res. 1, 297-302.

Gomez, K.A., Gomez, A.A., 1984. Statistical procedures for agriculture research, $2^{\text {nd }}$ ed. John Wiliy and Sons Editor Inc., USA, pp. 129-184. .

Hitokoto, H., Morozumi, S., Wauke, T., Sakai, S., Kurata, H., 1978. Fungal contamination and mycotoxin detection of powdered herbal drugs. Applied and environmental microbiology 36, 252-256.

Iacumin, L., Chiesa, L., Boscolo, D., Manzano, M., Cantoni, C., Orlic, S., Comi, G., 2009. Moulds and ochratoxin $\mathrm{A}$ on surfaces of artisanal and industrial dry sausages. Food microbiology 26, 65-70.

International Commission of Microbiological Specification for Foods (ICMSF), 1996. Microorganisms in Food. 1- Their Significance and methods of enumeration. 3rd Ed. Univ. Toronto, Canada.

King, J.A.D., Pitt, J.I., Beuchat, L.R., Corry, J.E.L., 1986. Methods for the Mycological Examination of Food. Plenum Press, NY. .

Lin, J., Yeh, K.S., Liu, H.T., Lin, J.H., 2009. Staphylococcus aureus isolated from pork and chicken carcasses in Taiwan: prevalence and antimicrobial susceptibility. Journal of food protection 72, 608-611.

Maheux, A.F., Picard, F.J., Boissinot, M., Bissonnette, L., Paradis, S., Bergeron, M.G., 2009. Analytical comparison of nine PCR primer sets designed to detect the presence of Escherichia coli/Shigella in water samples. Water research 43, 3019-3028.

Martin-Sanchez, A.M., Chaves-Lopez, C., Sendra, E., Sayas, E., Fenandez-Lopez, J., Perez-Alvarez, J.A., 2011. Lipolysis, proteolysis and sensory characteristics of a Spanish fermented dry-cured meat product (salchichon) with oregano essential oil used as surface mold inhibitor. Meat science $89,35-44$.

McEvoy, J.M., Doherty, A.M., Sheridan, J.J., ThomsonCarter, F.M., Garvey, P., McGuire, L., Blair, I.S., McDowell, D.A., 2003. The prevalence and spread of Escherichia coli $\mathrm{O} 157: \mathrm{H7}$ at a commercial beef abattoir. Journal of applied microbiology 95, 256-266.

Mizakova, A., Pipova, M., Turek, P., 2002. The occurrence of moulds in fermented raw meat products. Czech J. Food Sci. 3, 89-94.

Mossel, D.A.A., Corry, J.E.L., Struijk, C.B., Baird, R.M., 1995. Essentials of the microbiology of foods: a textbook for advanced studies. Chichester (England): John Wiley \& Sons, pp. 287-289.

Potter, N.N., 2001. Food Science, $3^{\text {rd }}$ ed. the AVI Publishing Co. Inc., New York, USA.

Quinn, P.J., Markey, B.K., Carter, M.E., Donnelly, W.J., Leonard, F.C., Maguire, D., 2002. Veterinary Microbiology and Microbial Disease, $1^{\text {st }} \mathrm{ed}$. Blackwell Science Ltd, Oxford.

Stoica, M., Stoean, S., Alexe, P., 2014. Overview of biological hazards associated with the consumption of the meat products. J. Agro. Alim. Proc. Technol. 20, 192-197.

Tambekar, D.H., Jaiswal, V.J., Dhanorkar, D.V., Gulhane, P.B., Dudhane, M.N., 2008. Identification of microbiological hazards and safety of ready-to-eat food vended in streets of Amravati City, India. J. Appl. Biosci. 7, 195-201.

Weinstein, J., 1991. The clean restaurant. II: Employee hygiene. Restaurants \& institutions 101, 138-139, 142, 144 passim. 